\title{
Study on the valuation of music copyright in China
}

\author{
Yongchen $\mathrm{Li}^{1}$, a , Yang Liü, b* \\ ${ }^{1}$ North China Electric Power University, Baoding, China \\ ${ }^{2}$ North China Electric Power University, Baoding, China \\ abngdftc@163.com, bncepu_liuyang@163.com
}

Keywords: Culture Industry; Music copyright; Copyright Valuation.

Abstract. Since the 18th CPC National Congress, the development of cultural industry gets more and more attention and the demand of cultural industry of intangible assets valuation is increasing. This article will research on music copyright, mainly focus on the influence factors of music copyright value on the basis of economic features and source of value, and then discuss the present situation and problems of music copyright valuation, finally put forward proposal to solve these problems. I'm looking forward that this paper plays a positive role in the development of music copyright valuation.

\section{Introduction}

The report of 18th CPC National Congress predicted that cultural industry will become the pillar industry of the national economy, the economic value added of cultural industries will share $5 \%-6 \%$ of GDP by 2020 .

As an important branch of the cultural industry, the rapid development of the digital music has brought great changes to the music industry in recent years. Although the trend of traditional record industry is declining, the value of music copyright is increasing, music has been ranked the top three Internet applications. Copyright assets have become a core part of their commercial value for record companies. Management and operation of copyright asset and corporate restructuring, mergers and acquisitions involving copyright trading, financing, tort claims and other economic activities, which has an urgent need to assess the music copyright.

\section{Economic characteristics of music copyright}

Music copyright is a legal right that grants the music creator of an original work the exclusive rights to its use and distribution, usually for a limited time. As an asset, music copyright has obvious economic characteristics.

The non-entity of music copyright. As a form of intangible assets, the music copyright has no specific physical form, but exists in the tape, CD recordings and other physical carriers. Although purchasers buy the concrete material goods, but what actually get are invisible spirit products, which is reflect of copyright value in the true sense.

The scarcity of music copyright. Even if it took a lot of manpower and financial resources to incentive or search for the creator of passion, it is difficult to obtain the music work that is both in high artistic value and in high market value, which is outstanding performance in this scarcity. A large number of ripping of classic songs in music Market shows the scarcity of music copyright.

The exclusivity of music copyright. With the "exclusive" feature inherently, music copyright is owned by a particular subject. Legal protection and privacy protection prevent others from free possession or use. Based on this exclusivity, rights holders obtain premium income through exclusivity and monopoly.

The profitability of music copyright. As a form of intangible assets, the prerequisite is that copyright should bring benefits to copyright owners. Music copyright from musical works by music producer can be copied to a certain medium and then sold by the issuer or sold to the media that are authorized to play. 
The weak correspondence of music copyright. Musical work comes from creative labor and public reaction to it has great randomness and chance. There is a possibility that market reaction will be not applauded on the basis of early high investment to create and record music. It is also possible to spend a small pre-production but has gained a high market value. It lacks obvious correspondence between development costs and benefits of copyright.

\section{Value source of music copyright}

The valuation of music copyright, namely, is an assessment of the economic value of music copyright. We should clear the source of music rights value first of all to effectively and accurately assess the value of music copyrights.

Making music requires a significant investment of human, technical and financial cost. Through the transmission rights, Music copyright value will be achieved finally. Convenient mode of transmission, wide range of transmission, transmission cost and the dissemination of the audience are important ways to realize the value of copyright.

The copyright monopoly is also the assurance of source of music copyright value. Music works condense the mental work of the musical creation, is the result of the transformation of their inspiration and wisdom, and the music copyright is the embodiment of this kind of result in the legal level. The protection of the copyright of the law makes it a monopoly, which is the basis for the creation, protection, management and dissemination of the works. It is this kind of monopoly power that can bring the economic benefits to the music copyright holder, and it is a powerful guarantee for the formation of the value of the music copyright.

\section{Factors affecting the value of music copyright}

Music copyright value will be influenced by the valuation requirements, music works and music copyright. We need to consider the factors from these three aspects in the valuation of the music copyright:

The aspect of music work. Musical works have condensed the creators of intellectual labor, its art uniqueness is the basis of the legal protection, so music quality is an important factor that influences the value of copyright. Generally speaking, high quality music that needs more creative input and more difficult to create is worth to get higher compensation because of its unique and irreplaceable value. As an art work, the quality of musical works is reflected in aesthetic feeling, utility and emotional appeal. Excellent music works can bring a sense of hearing and emotional appeal to the audience, and meet the spiritual demands of the audience.

As a kind of intangible asset, the brand of the creator, as well as the brand of music, respects the quality of music to a certain extent. The higher the creator, the higher the market demand, the higher the value of the music copyright.

The aspect of valuation requirements. Different evaluation purposes will produce different results. Music copyright involves a lot of economic activities. We should research from three aspects including transfer of copyright, copyright pledge and tort compensation. If the purpose of valuation is to deal with music copyright, the evaluation criteria is the agreement between the two parties. The purpose of valuation is to pledge the copyright of the music, and the valuation criteria should be the market value.

In addition, the use of different assessment methods will also make the assessment results have differences. For the music copyright assessment, the income method, market method and cost method are used in domestic and international practice, but sometimes the difference among the results of different methods and guidelines of valuation agencies is very large. Of course, this difference is largely due to the difference in the parameters of different methods.

The aspect of copyright. The value of music copyright will be influenced by many factors, such as the life, authority, independence, limitation and integrity of the copyright. 
The life of copyright is the legal protection of copyright. The longer the protection period, the longer the use of the music copyright holder. The value of the music copyright will be higher.

After the completion of the work of the music, the creator will not spread all by themselves. Most will authorize publisher to issue. Licensing and transfer are the most common form of authorization. In most cases, the value of licensing is lower than the valuation of the transfer.

In some cases, the creator or owner of a musical work is more than one, and there is a phenomenon of multiple copyrights or multiple right subjects that will reduce the degree of independence of the music copyright. Licensing and transfer of music copyright need the consent of all right subjects. Complex copyright ownership will also reduce the value of copyright in a certain extent.

Musical works will be subject to reasonable use and statutory licensing restrictions. When there are more restrictions, there will be more loss of copyright owners, and the value of music copyright will be lower.

The full extent of copyright is reflected in the two aspects of the registration and the remaining rights. Chinese law provides that general works take the principle of voluntary registration, the registration process is not an essential condition for the production of musical copyright and the registration of copyright in the music copyright dispute can be used as a proof of the right holder. This will reduce the cost of litigation of the right person so as to indirectly affect the value of music copyright. Copyright as a collection of many property sub rights, all the sub rights can be separately licensed or transferred. The rest of the rights form the remaining rights, so that the copyright is no longer complete. The more complete the music copyright, the higher the value.

\section{Present situation and problems of music copyright valuation}

Cultural industry and copyright valuation in China started late, the theoretical research is still less. Music industry is a branch of cultural and creative industries, but music copyright valuation has not received enough attention and lack of relevant research. The focus of the study is on the use of the non - traditional method in the music copyright valuation, and there is no system for the valuation of music copyright.

With the improvement of people's copyright awareness in recent years, some music infringement events get more attention. From the music copyright holder to the record company, they all have strengthened the music copyright the maintenance and increased cases of copyright value appraisal so as to promote the development of practice. Although there is great development in music copyright valuation, many problems still exist.

First, the music copyright valuation has not formed a complete and unified system. In 2010, the introduction of 《the evaluation and guidance on the copyright assets》 has a great effect on the copyright valuation, but there is still no unified quantitative criteria and valuation system in valuation boundary. There is a big difference between the results of the same object in different valuation methods and relevant parameters. Even worse, it will reduce the level of acceptance of the rights holders and the parties to the transaction. If things go on like this, the valuation result will lose its application value.

Second, method can not meet the needs of assessment. The main use of the current music copyright valuation is still the three traditional methods of cost method, market method and income method. Development cost or replacement cost are the basis for the valuation of copyright value in cost method. And because of the weak correspondence of music copyright cost and benefit, the cost can not accurately reflect the value of music copyright. Market method is comparing object with more than three similar reference objects with successful trading history in market to value the copyright. Most of the music works have unique artistic and monopoly, it is difficult to find similar music works as the valuation reference in the market, which limits the use of market method in a large extent. As the most widely used method, the income method is used to estimate the copyright value by forecasting the cash flow and discounting it into the current value in the whole cycle. But future cash flow forecast in 
income method is based on historical data, and the change of the music copyright income is difficult to predict, so we can not simply identify income can still be obtained in future.

Third, staff quality needs to be improved. Music copyright valuation in China starts late and develops in short time. Related valuation experience and lessons are too insufficient that there are a few cases can refer in practice. In addition, music copyright covers a wide range, which requires staff not only have professional valuation, financial and economic knowledge but also have intellectual property and copyright awareness. But most staffs do not so much knowledge of music copyright valuation that the indirect income and social benefits are not accurate. There exist overestimate and underestimate phenomenon in the valuation process.

\section{Suggestions for the above problems}

At the present stage, the management and valuation of music copyright has profound significance to the music industry and the whole culture industry. Only by improving the environment of the music copyright valuation, can we guarantee the accuracy and validity of the valuation, and promote the development of music industry and cultural industry.

First of all, we should establish a sound system for the valuation of music copyright. The music copyright valuation system includes a series of factors, such as subject, object, purpose, value types and valuation method. The relevant departments of the State shall establish a specialized copyright assessment and management mechanism, perfect the valuation system, and guide the development of the copyright work in the macro.

Secondly, we should establish the standard of the music copyright transaction database. Music copyright valuation is in accordance with a certain assessment procedures, applies specific valuation method and makes value judgment based on a certain market transaction data. Based on the full symmetry of the music copyright valuation information and the reference for other works, music copyright valuation needs to establish a standard database.

Finally, we should improve the professional quality of the staff. To make music copyright valuation results accurate and effective, it is essential that the staffs master professional valuation, financial and economic knowledge and copyright awareness in addition.

\section{Conclusions}

China has already put the cultural industry in the strategic position of national economy pillar industry. In the future for a long time, it is the economic development trend that the cultural industry has become the new economic growth point. In this trend, the music industry will usher in prosperity and development opportunities. The demand of scientific and effective music copyright valuation will be growing. Through theoretical research and practice to improve the music copyright valuation system, we hope to find a suitable situation method, improve the valuation situation, and make development in music industry and culture industry.

\section{Reference}

[1] Li Man. Application of analytic hierarchy process in the evaluation of the value of musical works [J]. Friends of accounting, 2013 (08): 37-40.

[2] Zheng Wen. The construction of the copyright valuation standard in audio-visual industry in China [J]. China publishing, 2009 (10): 26-29.

[3] Wang Zhiyuan. Economic nature and value realization of copyright [J]. Editor of the friends, 2012 (07): 97-100.

[4] Hou Hanyu, Yuan Huang. Study on the object of copyright value evaluation and its influence factors [J]. China assets assessment, 2011 (08): 11-14. 